\title{
Realization of National Institute for Standards (NIS - Egypt) Viscosity Scale in Wide Temperature Ranges
}

\author{
Eman M. mohamed ${ }^{1}$, Mostafa. M. Mekawy ${ }^{1}$, Hoda Mohamed Abo Dorra ${ }^{2}$ \\ 1.National Institute for Standards, Tersa St., El Haram, Giza 12211, Egypt. \\ 2. Physics Department, Faculty of Women for Arts, Science and Education- Ain Shams University
}

\begin{abstract}
A new viscosity bathes has been entered the services in Thermal Metrology LaboratoryNational Institute for Standards, NIS-Egypt in order to use in maintain and extend the national viscosity scale in wide temperature ranges, international comparison and routine calibration of viscometers. The medium of the bath should be homogenous enough in temperature so many thermal factors taken into account to estimate the temperature gradient, homogeneity, stability and thermal profile distribution with the related uncertainty to each parameter. The study carried out by two Standards Platinum Resistance Thermometer (SPRT) calibrated at fixed point according to ITS-90. A number of glass capillary viscometers have been selected and arranged into six groups. The selected viscometers and oils realize NIS viscosity scale in wide temperature ranges from $-30{ }^{\circ} \mathrm{C}$ up to $100{ }^{\circ} \mathrm{C}$.
\end{abstract}

Keywords: Viscosity, Viscometer, ITS-90, SPRT, Fixed Points, Uncertainty, Scale.

\section{Introduction}

Viscosity laboratory decided to extend the national viscosity scale in low temperature range down to $-30^{\circ} \mathrm{C}$, new viscosity baths works with low temperature range using dry denatured ethanol is used as the bath medium because its property to absorb moisture from the atmosphere is removed from it. The oil bath model Koehler LKV4000 low temperature kinematic viscosity bath contains several upper holes to receive four viscometers at the same time; there is an additional small hole to insert the Standard Platinum Resistance Thermometers (SPRTs) to measure the temperature variation during the viscosity measurements. The cooling unit within the bath stabilize the bath temperature to desired setting within $\pm 0.02^{\circ} \mathrm{C}$.

The bath is filled with approximately $14 \mathrm{~L}$ of ethanol as a medium to put inside it the viscometers in order to calibrate glass viscometer under test with references known oils or even known viscometers with unknown oils under test. The main target is realize the kinematic viscosity tests with glass capillary viscometers according to the ASTM D445 (ASTM, 1992) test method and related test specifications. The SPRTs SN 234, 247 has been calibrated at fixed point according to ITS-90 (Preston-Thomas, 1990).

Corresponding author: Eman Mohy El Dien Mohamed

Tel.: 01003928656, E-mail address: Eman.mohyeldien@gmail.com . 


\section{Materials and Methods}

\section{Experimental arrangement}

\subsection{Thermal Profile Characterization of the bath}

The bath filed with 14L of ethanol then the SPRTs have been inserted into the medium at different positions and levels. Five levels taken into the account from the top side down to the bottom separate equally from each other's, at each level the thermometer inserted in five positions as four at the corners and one at the center of the level as shown in Figure 1. So, twenty five position introduced into the study at each temperature set point, the range of interest is from $-30{ }^{\circ} \mathrm{C}$ up to $10{ }^{\circ} \mathrm{C}$. The measurements carried out at $-30^{\circ} \mathrm{C},-20^{\circ} \mathrm{C},-10{ }^{\circ} \mathrm{C}$ and $10{ }^{\circ} \mathrm{C}$. The two SPRT connected at the same time to resistance bridge model ASL F700 conjugated with standard resistor and the measuring system connected to PC working under LABVIEW environment.

Homogeneity is the main parameter should be studied to optimize and establish a suitable uniform medium realize the National Viscosity Scale. In order to find a closed value to the homogeneity as possible, thermal gradient taken into account and observed as a change of a temperature readings of a thermometer according to a change of its position inside a calibration bath (Pornpatkul, 2012). Basic gradients that can be observed are vertical and horizontal gradient but sometimes more appropriate to define axial and a radial gradient. Axial gradient is determined as maximum temperature difference between two different positions in axial direction. The radial gradient is a maximum temperature difference between two different positions in a radial direction. So, three thermal factors were discussed as follows;

\subsubsection{Thermal Profile Distribution}

Consider that the temperature $T_{P_{Y}}^{L x}$ denotes to the temperature at level Lx and position Py, the two SPRT measure the temperature at different positions and levels as shown in figure 1 , table1 

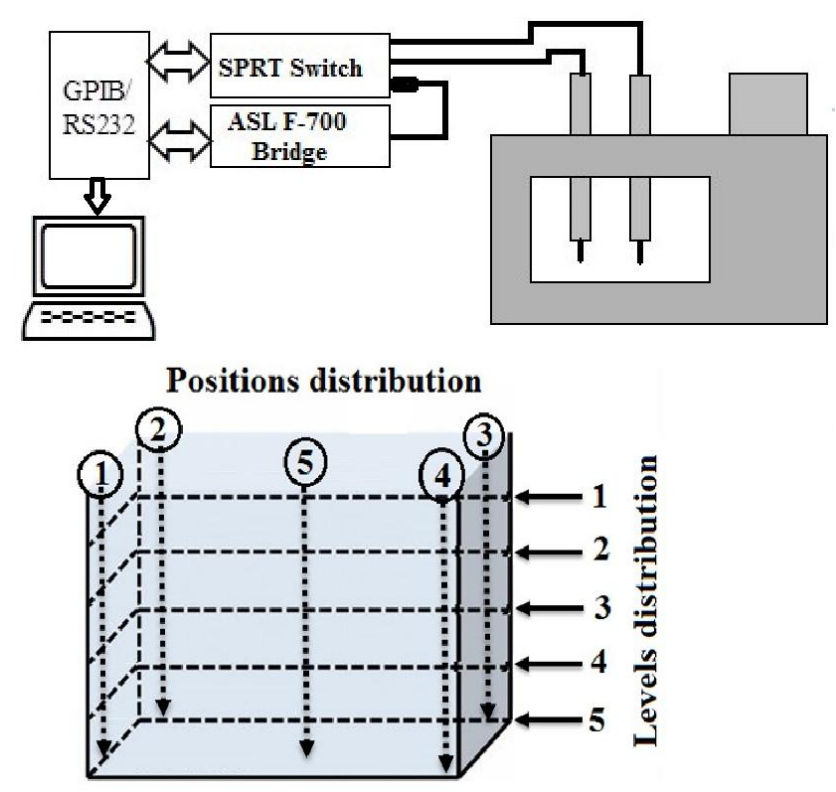

Figure 1. Schematic diagram of levels and position distribution Table 1. Distribution of the temperature measurements using SPRT SN 234

\begin{tabular}{|c|c|c|c|c|c|c|}
\hline $\mathbf{L}$ & \multicolumn{6}{|c|}{ Temperature $\left\langle T_{P y}^{L x}\right\rangle^{*}$ SPRT 234} \\
\hline \multirow{6}{*}{1} & $\mathrm{P}$ & $\overline{\mathrm{T}}$ & -30.00 & -20.00 & -10.00 & 10.00 \\
\hline & 1 & $\left\langle T_{p 1}^{L 1}\right\rangle$ & -30.00138 & -20.02123 & -10.02138 & 10.02811 \\
\hline & 2 & $\left\langle T_{p 2}^{L 1}\right\rangle$ & -30.00149 & -20.02127 & -10.02154 & 10.02823 \\
\hline & 3 & $\left\langle T_{p 3}^{L 1}\right\rangle$ & -30.00152 & -20.02129 & -10.02167 & 10.02841 \\
\hline & 4 & $\left\langle T_{p 4}^{L 1}\right\rangle$ & -30.00144 & -20.02139 & -10.02172 & 10.02852 \\
\hline & 5 & $\left\langle T_{p 5}^{L 1}\right\rangle$ & -30.00131 & -20.02156 & -10.02183 & 10.02857 \\
\hline \multirow{6}{*}{2} & $\overline{\mathrm{P}}$ & $\mathrm{T}$ & $\begin{array}{c}-30.00 \\
\end{array}$ & -20.00 & -10.00 & $\mathbf{1 0 . 0 0}$ \\
\hline & 1 & $\left\langle T_{p 1}^{L 2}\right\rangle$ & -30.00121 & -20.02134 & -10.02136 & 10.02822 \\
\hline & 2 & $\left\langle T_{p 2}^{L 2}\right\rangle$ & -30.00124 & -20.02156 & -10.02176 & 10.02847 \\
\hline & 3 & $\left\langle T_{p 3}^{L 2}\right\rangle$ & -30.00157 & -20.02144 & -10.02149 & 10.02833 \\
\hline & 4 & $\left\langle T_{p 4}^{L 2}\right\rangle$ & -30.00156 & -20.02165 & -10.02159 & 10.028342 \\
\hline & 5 & $\left\langle T_{p 5}^{L 2}\right\rangle$ & -30.00192 & -20.02154 & -10.02158 & 10.02897 \\
\hline \multirow{6}{*}{3} & $\mathbf{P}$ & $\mathbf{T}$ & -30.00 & -20.00 & -10.00 & 10.00 \\
\hline & 1 & $\left\langle T_{P 1}^{L 3}\right\rangle$ & -30.00198 & -20.02183 & -10.02222 & 10.02865 \\
\hline & 2 & $\left\langle T_{p 2}^{L 3}\right\rangle$ & -30.00204 & -20.02194 & -10.02234 & 10.02860 \\
\hline & 3 & $\left\langle T_{p 3}^{L 3}\right\rangle$ & -30.00213 & -20.02211 & -10.02256 & 10.02880 \\
\hline & 4 & $\left\langle T_{p 4}^{L 3}\right\rangle$ & -30.00209 & -20.02256 & -10.02277 & 10.02832 \\
\hline & 5 & $\left\langle T_{p 5}^{L 3}\right\rangle$ & -30.00221 & -20.02252 & -10.02281 & 10.02854 \\
\hline \multirow{4}{*}{4} & $\mathrm{P}$ & $\mathrm{T}$ & -30.00 & -20.00 & -10.00 & $\overline{10.00}$ \\
\hline & 1 & $\left\langle T_{p 1}^{L 4}\right\rangle$ & -30.00202 & -20.02238 & -10.02321 & 10.02910 \\
\hline & 2 & $\left\langle T_{p 2}^{L 4}\right\rangle$ & -30.00218 & -20.02241 & -10.02333 & 10.02930 \\
\hline & 3 & $\left\langle T_{p 3}^{L 4}\right\rangle$ & -30.00232 & -20.02244 & -10.02345 & 10.02949 \\
\hline
\end{tabular}




\begin{tabular}{|c|c|c|c|c|c|c|}
\hline & 4 & $\left\langle T_{p 4}^{L 4}\right\rangle$ & -30.00241 & -20.02253 & -10.02377 & 10.02961 \\
\hline & 5 & $\left\langle T_{p 5}^{L 1}\right\rangle$ & -30.00221 & -20.02259 & -10.02281 & 10.02983 \\
\hline \multirow{6}{*}{5} & $\overline{\mathrm{P}}$ & $\mathrm{T}$ & -30.00 & -20.00 & -10.00 & 10.00 \\
\hline & 1 & $\left\langle T_{P 1}^{L 5}\right\rangle$ & -30.00265 & -20.02244 & -10.02312 & 10.03017 \\
\hline & 2 & $\left\langle T_{p 2}^{L 5}\right\rangle$ & -30.00273 & -20.02257 & -10.02319 & 10.03032 \\
\hline & 3 & $\left\langle T_{p 3}^{L 5}\right\rangle$ & -30.00279 & -20.02269 & -10.02341 & 10.03048 \\
\hline & 4 & $\left\langle T_{p 4}^{L 5}\right\rangle$ & -30.00281 & -20.02274 & -10.02369 & 10.03069 \\
\hline & 5 & $\left\langle T_{P 5}^{L 5}\right\rangle$ & -30.00280 & -20.02272 & -10.02389 & 10.03083 \\
\hline
\end{tabular}

\subsubsection{Thermal Stability}

The stability of the bath shows lower variation within the regulation specification of the bath. The fluctuation was monitored at different positions and levels as shown in figure 2 for SPRT SN-234 at setting point $20.0^{\circ} \mathrm{C}$. The stability calculated at each level in the center point for continuous several hours (Ghazanfar, 2013).

$$
T_{\text {atability }}=\frac{\left(\Delta t_{\max }-\Delta t_{\min }\right)}{2}
$$

During the progressive study of the performance of the Bath, it is found that the stability was better than $0.015^{\circ} \mathrm{C}$.

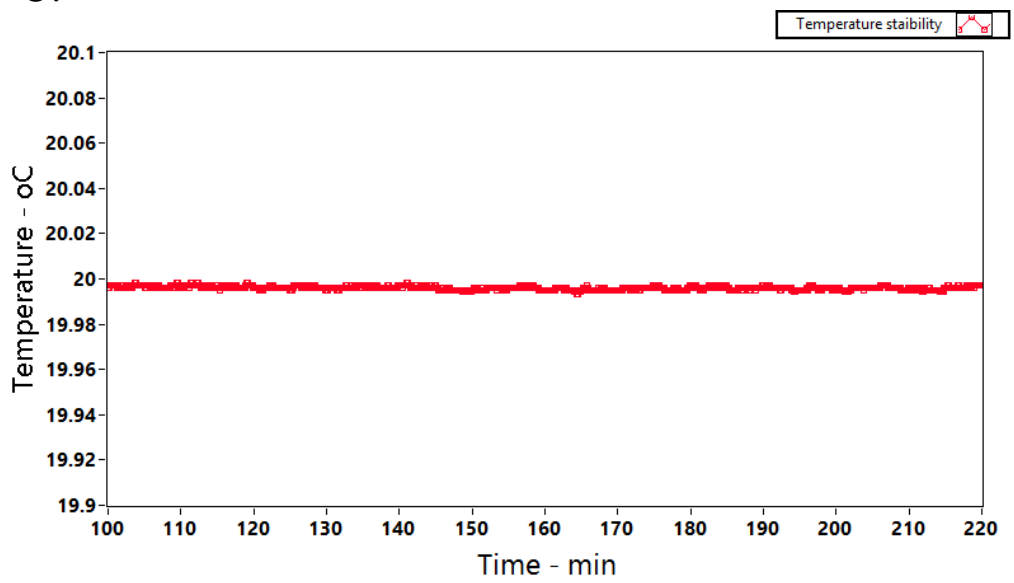

Figure 2. Temperature stability at the canter of the bath at $20.0{ }^{\circ} \mathrm{C}$.

\subsubsection{Thermal Gradient}

The vertical gradient in a bath is termed "axial uniformity". The horizontal gradient in a bath is termed "radial uniformity" (EURAMET, 2011).

\subsubsection{Vertical Thermal Gradient}

Figures from three to ten are shown the temperature gradient due to thermometer depths through five levels at different setting points for SPRTs SN 234 and SN 247. 


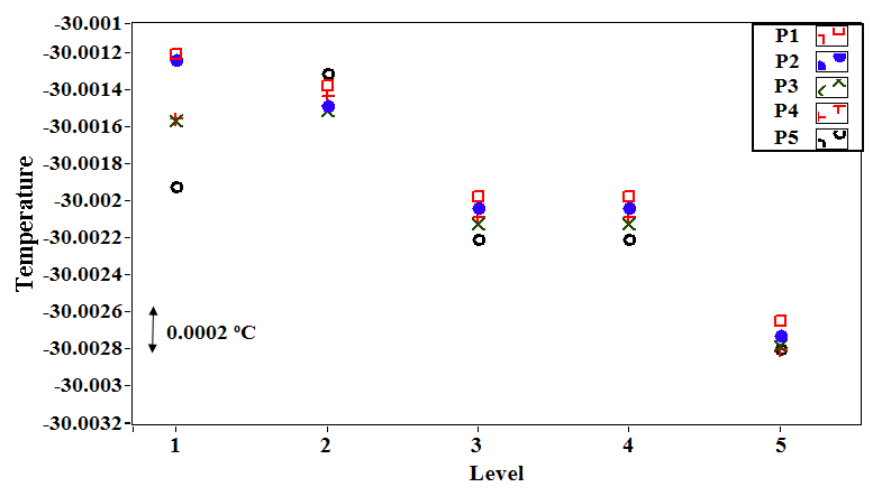

Figure 3. Thermal axial gradient at $-30.0{ }^{\circ} \mathrm{C}$ for SPRT SN 234

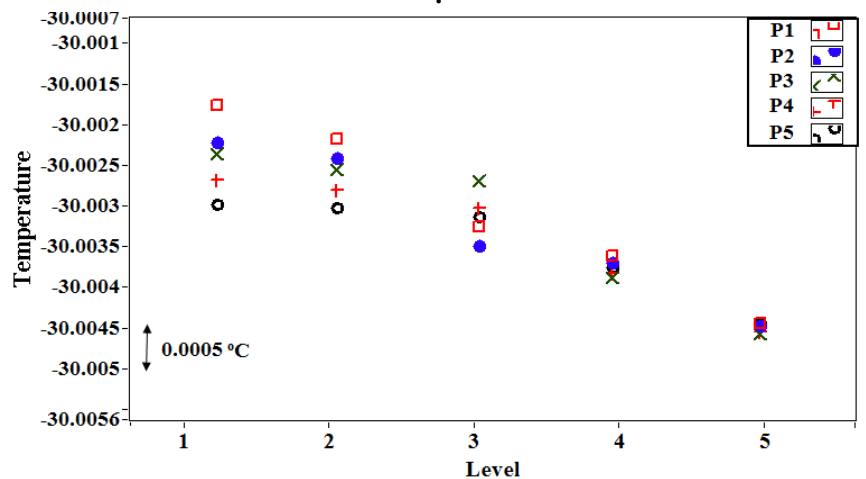

Figure 4. Thermal axial gradient at $-30.0{ }^{\circ} \mathrm{C}$ for SPRT SN 247.

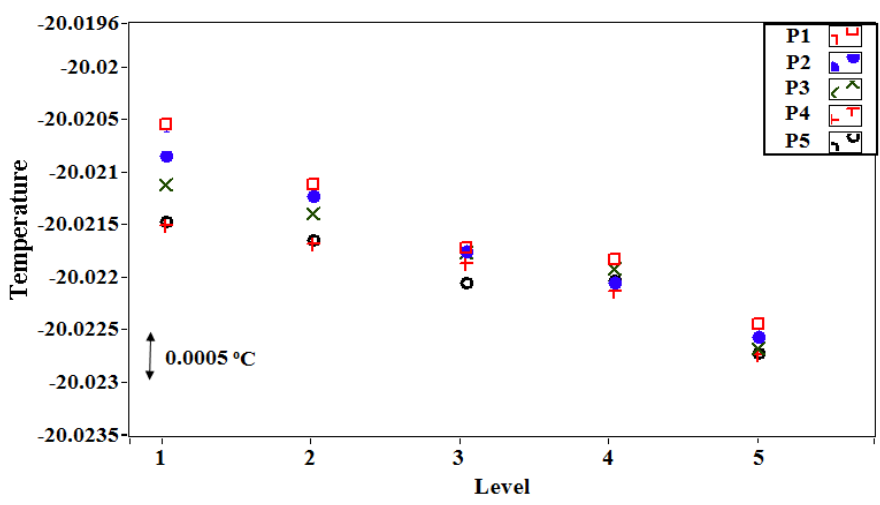

Figure 5. Thermal axial gradient at -20.0 oC for SPRT SN 234 .

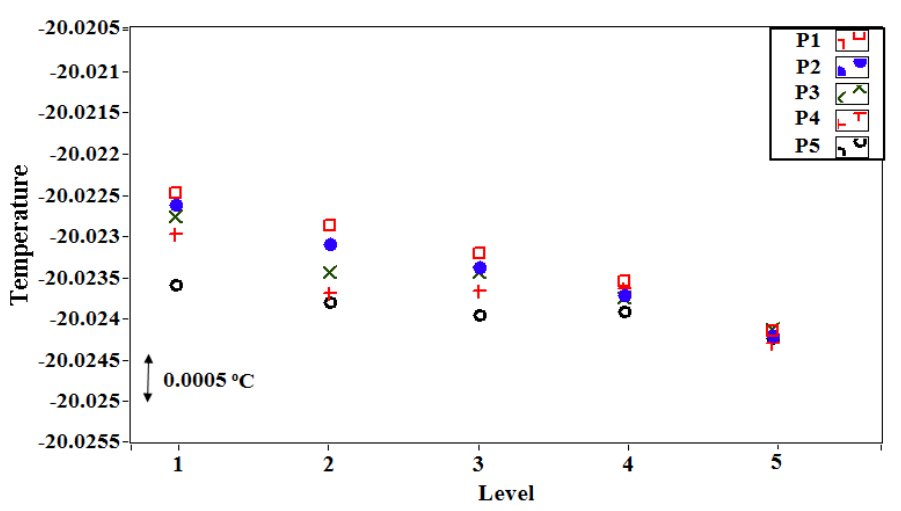

Figure 6. Thermal axial gradient at $-20.0{ }^{\circ} \mathrm{C}$ for SPRT SN 247. 


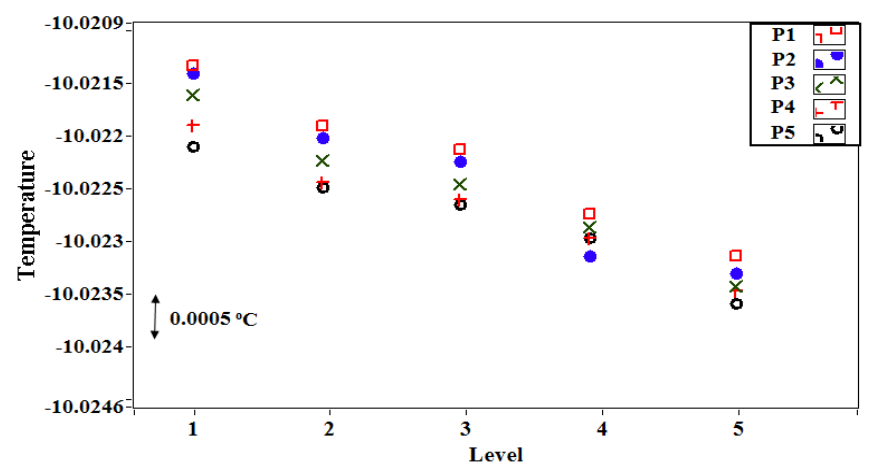

Figure 7. Thermal axial gradient at $-10.0{ }^{\circ} \mathrm{C}$ for SPRT SN 234.

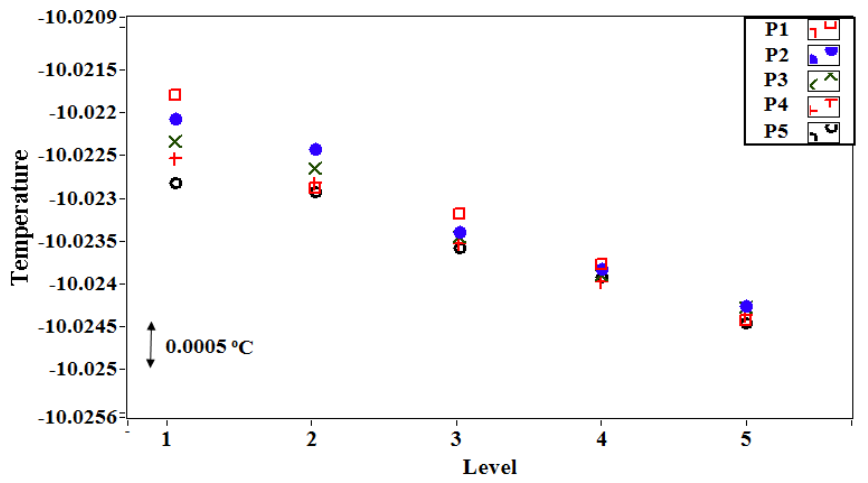

Figure 8. Thermal axial gradient at $-10.0{ }^{\circ} \mathrm{C}$ for SPRT SN 247.

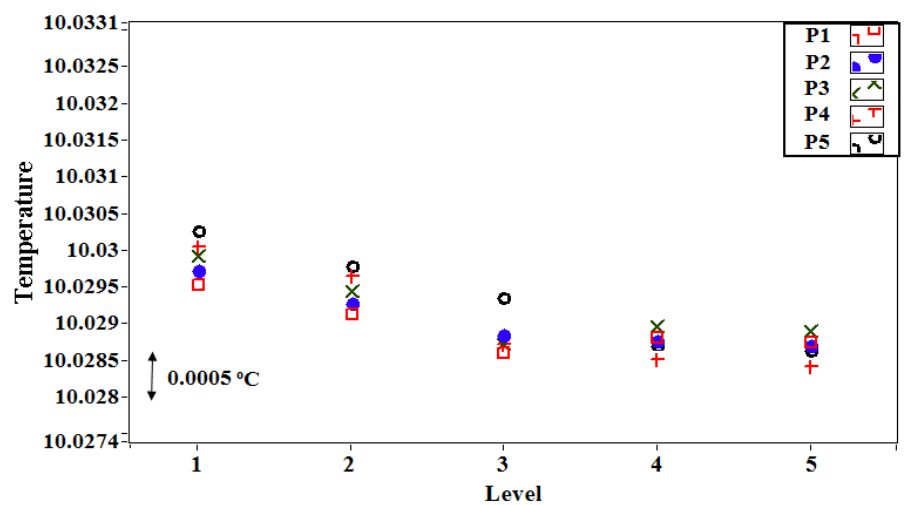

Figure 9. Thermal axial gradient at $10.0{ }^{\circ} \mathrm{C}$ for SPRT SN 234 .

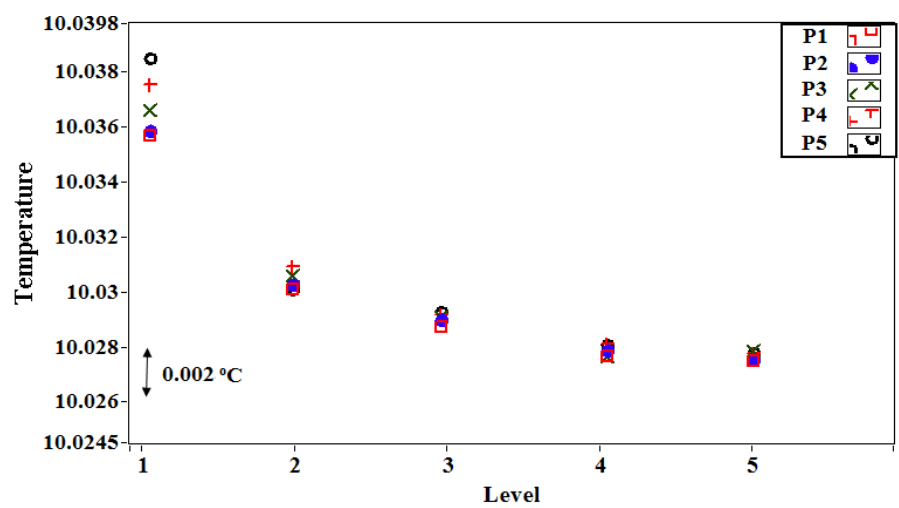

Figure 10. Thermal axial gradient at $10.0{ }^{\circ} \mathrm{C}$ for SPRT SN 247. 


\subsubsection{Horizontal Thermal Gradient}

Figures from 11 to 18 show the temperature gradient due to thermometer positions at each level at different setting points for SPRTs SN 234 and SN 247.

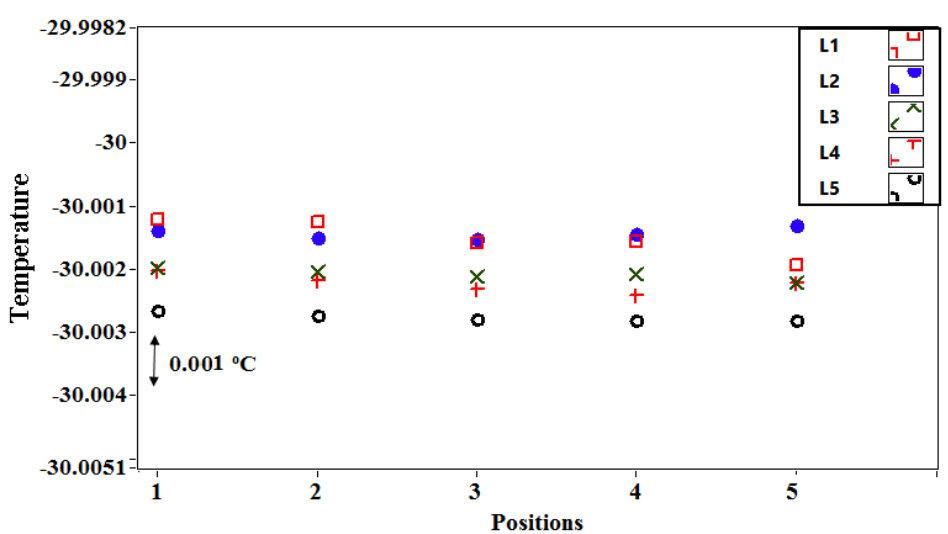

Figure 11. Thermal radial gradient at $-30.0{ }^{\circ} \mathrm{C}$ for SPRT SN 234.

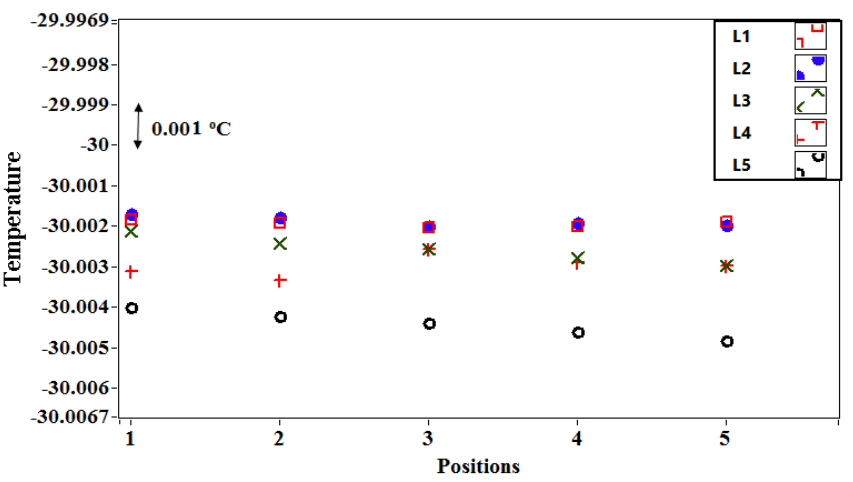

Figure 12. Thermal radial gradient at $-30.0^{\circ} \mathrm{C}$ for SPRT SN 247.

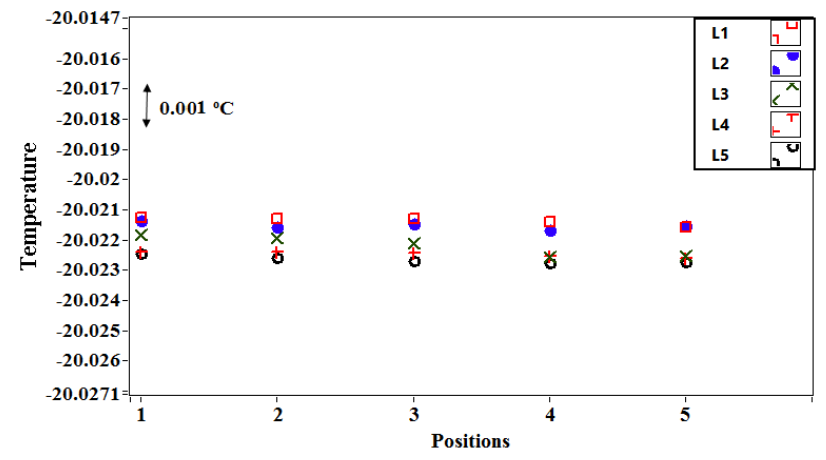

Figure 13. Thermal radial gradient at $-20.0{ }^{\circ} \mathrm{C}$ for SPRT SN 234. 


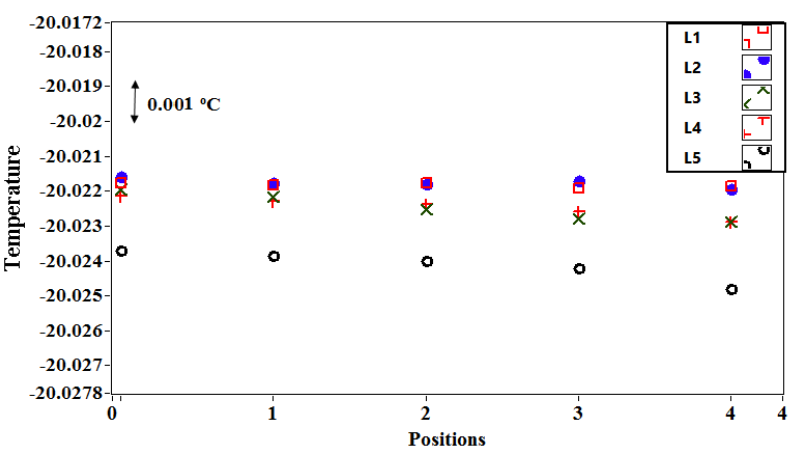

Figure 14. Thermal radial gradient at $-20.0{ }^{\circ} \mathrm{C}$ for SPRT SN 247 .

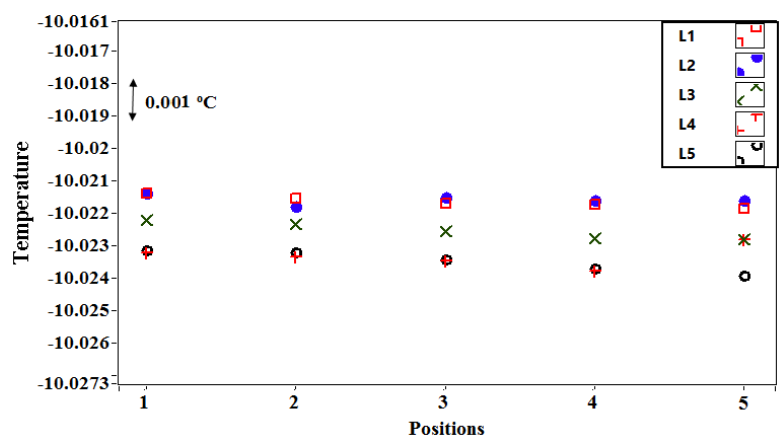

Figure 15. Thermal radial gradient at $-10.0{ }^{\circ} \mathrm{C}$ for SPRT SN 234 .

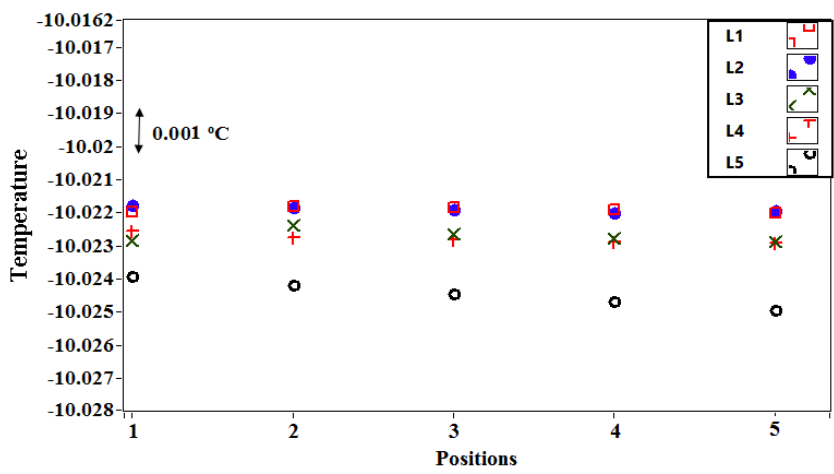

Figure 16. Thermal radial gradient at $-10.0{ }^{\circ} \mathrm{C}$ for SPRT SN 247.

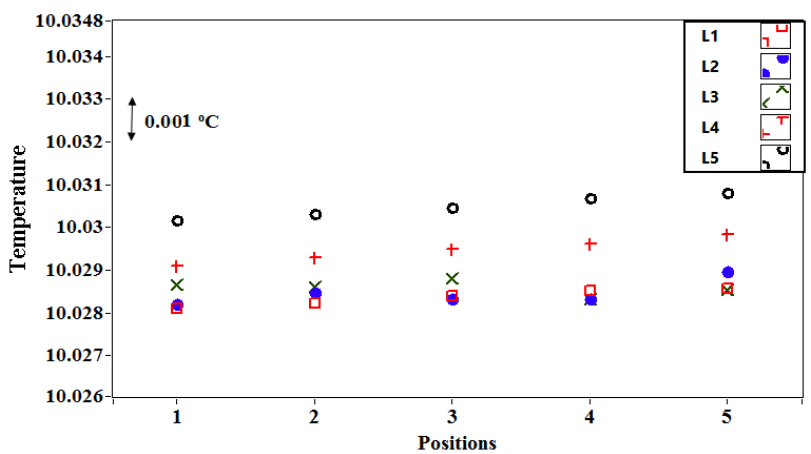

Figure 17. Thermal radial gradient at $10.0^{\circ} \mathrm{C}$ for SPRT SN 234 . 


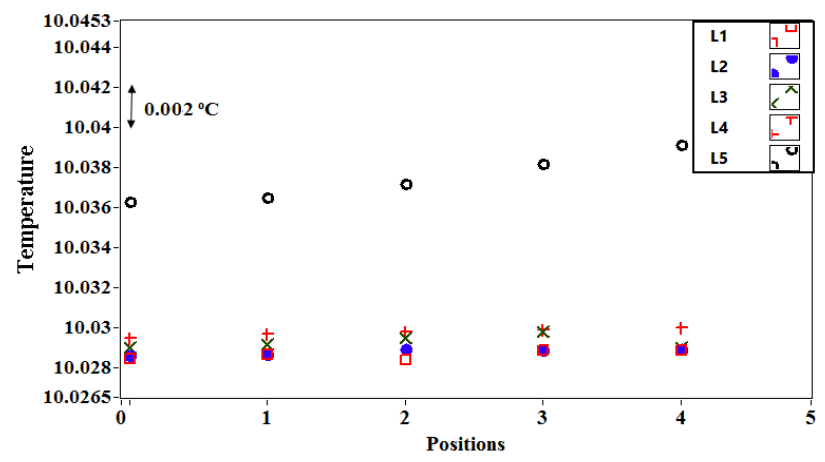

Figure 17. Thermal radial gradient at $10.0{ }^{\circ} \mathrm{C}$ for SPRT SN 247.

In order to calculated the thermal gradient which define from the following equation

$$
\nabla T=\frac{6 T}{\delta x}+\frac{6 T}{\delta y}+\frac{6 T}{\delta z}
$$

The study was carried out on two dimensions vertical and horizontal; the axial thermal gradient and the radial thermal gradient is equivalent to $0.014{ }^{\circ} \mathrm{C}$ and $0.012{ }^{\circ} \mathrm{C}$ respectively.

\subsection{Mounting the viscometers inside the bath}

The bathes can accommodate several viscometers simultaneously, the viscometers was fixed to stainless steel holder then it was inserted into the bath. From the transparent window of the bath, the operator can determine precisely the flow time of the certain oil as shown in figure 18.

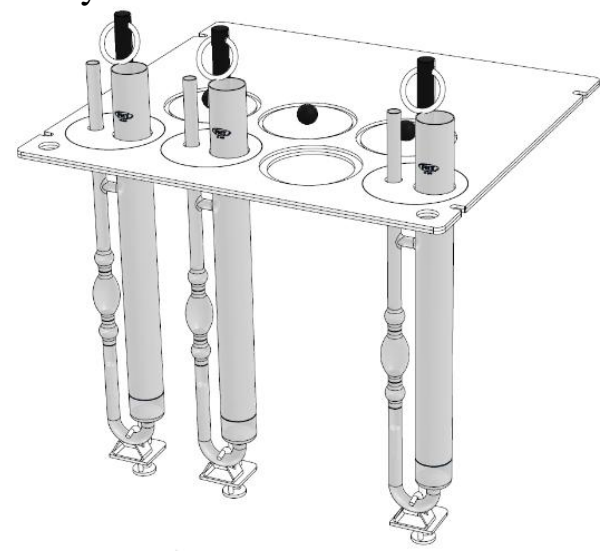

Figure 18. Mounting the viscometers into the bath.

\section{Results and Discussion}

Water is used to determine the viscometers constant of group 1 , to determine the viscosity of a liquid, whose viscosity is higher than the water. The viscosity is obtained by the average of the two viscometers using the following equation (A. Aliseda etal).

$$
v=\text { C. } \mathrm{t}
$$

Where, (v) is the kinematic viscosity values of the oil used, (C) is the instrumental constant, and $(\mathrm{t})$ is the time for reproducible volume of the liquid to flow under gravity. A number of glass capillary viscometers have been selected and arranged in six groups table 2 . 
Table (2) shows the viscometers used for each group, together with their identification data.

\begin{tabular}{|c|c|c|c|c|}
\hline Groups & Viscometers Type & Serial No. & Oils Used & Temperature \\
\hline 1 & $\begin{array}{l}\text { BS/U/SL/MV } \\
\text { BS/U/SL/MV } \\
\text { BS/U/SL/MV }\end{array}$ & $\begin{array}{l}6891 \\
6890 \\
6889\end{array}$ & Water & $20{ }^{\circ} \mathrm{C} \& 25^{\circ} \mathrm{C}$ \\
\hline 2 & $\begin{array}{l}\text { BS/U/SL/MV } \\
\text { BS/U/SL/MV } \\
\text { BS/U/SL/MV } \\
\text { UBBELOHDE } \\
\text { UBBELOHDE }\end{array}$ & $\begin{array}{c}6891 \\
6890 \\
6889 \\
5965 \\
36379\end{array}$ & n-nonan & $20^{\circ} \mathrm{C} \& 25^{\circ} \mathrm{C}$ \\
\hline 3 & $\begin{array}{l}\text { UBBELOHDE } \\
\text { UBBELOHDE } \\
\text { UBBELOHDE } \\
\text { UBBELOHDE } \\
\text { UBBELOHDE }\end{array}$ & $\begin{array}{c}6695 \\
5965 \\
3266 \\
6686 \\
39125 \\
\end{array}$ & 171306 & $-20{ }^{\circ} \mathrm{C}$ \\
\hline 4 & $\begin{array}{l}\text { UBBELOHDE } \\
\text { UBBELOHDE } \\
\text { UBBELOHDE } \\
\text { UBBELOHDE }\end{array}$ & $\begin{array}{c}5965 \\
39125 \\
2603 \\
2602\end{array}$ & 131012 & $-20{ }^{\circ} \mathrm{C}$ \\
\hline 5 & $\begin{array}{l}\text { UBBELOHDE } \\
\text { UBBELOHDE } \\
\text { UBBELOHDE } \\
\text { UBBELOHDE }\end{array}$ & $\begin{array}{c}6686 \\
39125 \\
5965 \\
36379\end{array}$ & 170310 & $100{ }^{\circ} \mathrm{C}$ \\
\hline 6 & $\begin{array}{l}\text { UBBELOHDE } \\
\text { UBBELOHDE }\end{array}$ & $\begin{array}{c}1392 \\
790\end{array}$ & 05101 & $25^{\circ} \mathrm{C}$ \\
\hline
\end{tabular}

For group one using master viscometers, double destilled water as a reference liquid table (3) gives the constants of each viscometer of this group. The constants were determined as an average value using double destilled water which has similar efflux time of the n-nonane oil at $20^{\circ} \mathrm{C}$ and $25^{\circ} \mathrm{C}$ ).

Table (3): Results of the constants for the viscometers of group No. (1) with related uncertainties.

\begin{tabular}{|c|c|c|}
\hline Viscometer Serial No. & Constant (C) $\mathbf{~ m m}^{2} / \mathbf{s}^{\mathbf{2}}$ & Uncertainty (UC) $\mathbf{~ m m}^{2} / \mathbf{s}^{2}$ \\
\hline 6891 & 0.001655 & $\pm 0.3 \%$ \\
6890 & 0.001992 & $\pm 0.3 \%$ \\
6889 & 0.002088 & $\pm 0.3 \%$ \\
\hline
\end{tabular}

* The uncertainties are referred to $95 \%$ confidence level and $\mathrm{k}=2$

For group two using oil n-nonane (Dullaert K, Mewis J ) as a transfer standard at $20{ }^{\circ} \mathrm{C}$ and $25^{\circ} \mathrm{C}$, the master viscometers in group one used to determine the viscosity of n-nonane then the viscosity of n-nonane used to determined the viscometers constant for the two remaining viscometers in this group, table (4).

Table (4): Results of the constants for the viscometers of group No. (1) with related uncertainties. 


\begin{tabular}{|c|c|c|c|c|}
\hline Viscometer & $\begin{array}{c}\text { n-nonane } \\
\text { Vscossity } \\
\text { No }\end{array}$ & $\begin{array}{c}\text { Average } \\
\text { Flow } \\
\text { Time } \\
\text { V=C.t }\end{array}$ & $\begin{array}{c}\text { Viscometer } \\
\text { Constant } \\
\mathbf{s}\end{array}$ & $\begin{array}{c}\text { Uncertainty } \mathbf{U}_{\mathbf{C}} \\
\mathbf{C}=\mathbf{V} / \mathbf{T}\end{array}$ \\
\hline 36379 & 0.931432 & 564.024 & 0.001651 & $\pm 0.3 \%$ \\
\hline 5965 & 0.931432 & 464.864 & 0.002004 & $\pm 0.3 \%$ \\
\hline
\end{tabular}

For group three, using oil No (171306) (Standard Reference Material 717A) as a transfer standard at $-20{ }^{\circ} \mathrm{C}$ the viscometers in group 3 with known constant which are coming from its calibration certificates used to determine the viscosity of the oil No (171306), table (5).

Table(5): Results of the viscosity of the oil No (171306) from viscometers constants

\begin{tabular}{|c|c|c|c|}
\hline $\begin{array}{c}\text { Viscometer } \\
\text { No }\end{array}$ & $\begin{array}{c}\text { Viscometer } \\
\text { Constant } \\
\text { C=V/T }\end{array}$ & $\begin{array}{c}\text { Average } \\
\text { Flow Time } \\
\text { s }\end{array}$ & $\begin{array}{c}\text { Oil No 171306 } \\
\text { Vscossity } \\
\mathbf{m m}^{2} / \mathbf{s}^{\mathbf{2}} \\
\mathbf{V = C . t}\end{array}$ \\
\hline 39125 & 0.005306 & 3616.54 & 19.18936124 \\
\hline 6695 & 0.02993 & 640.91 & 19.18233653 \\
\hline 3266 & 0.01092 & 1755.16 & 19.16638360 \\
\hline 6686 & 0.01046 & 1830.15 & 19.14336900 \\
\hline \multicolumn{3}{|c|}{ Average Viscosity } & 19.17036259 \\
\hline Uncertainty & $\pm 0.12 \%$ \\
\hline
\end{tabular}

For group four, using oil No (131012) as a transfer standard at $-20{ }^{\circ} \mathrm{C}$ the viscometers in group 4 with known constant which are coming from its calibration certificates used to determine the viscosity of the oil No (131012), table (6).

Table (6): Results of the viscosity of the oil No (131012) from viscometers constants.

\begin{tabular}{|c|c|c|c|}
\hline $\begin{array}{c}\text { Viscometer } \\
\text { No }\end{array}$ & $\begin{array}{c}\text { Viscometer } \\
\text { Constant } \\
\text { C=V/T }\end{array}$ & $\begin{array}{c}\text { Average } \\
\text { Flow } \\
\text { Time/ s }\end{array}$ & $\begin{array}{c}\text { Oil No 131012 } \\
\text { Vscossity } \mathbf{~ m m}^{\mathbf{2}} / \mathbf{s}^{\mathbf{2}} \\
\text { V=C.t }\end{array}$ \\
\hline 5965 & 0.002757 & 273.3867 & 0.753727 \\
\hline 39125 & 0.005306 & 146.00 & 0.774676 \\
\hline 2602 & 0.003512 & 211.36 & 0.742296 \\
\hline 2603 & 0.003464 & 214.2567 & 0.742185 \\
\hline \multicolumn{3}{|c|}{ Average Viscosity } & 0.753221 \\
\hline Uncertainty & $\pm 0.07 \%$ \\
\hline
\end{tabular}


For group five, using oil No (170310) as a transfer standard at $100{ }^{\circ} \mathrm{C}$ the viscometers in group 5 with known constant which are coming from its calibration certificates used to determine the viscosity of the oil No (170310), table 7.

Table (7): Results of the viscosity of the oil No (170310) from viscometers constants

\begin{tabular}{|c|c|c|c|}
\hline $\begin{array}{c}\text { Viscometer } \\
\text { No }\end{array}$ & $\begin{array}{c}\text { Viscometer } \\
\text { Constant } \\
\text { C=V/T }\end{array}$ & $\begin{array}{c}\text { Average } \\
\text { Flow Time/ s }\end{array}$ & $\begin{array}{c}\text { Oil No 171306 } \\
\text { Vscossity } \\
\mathbf{m m}^{2} / \mathbf{s}^{2} \\
\mathbf{V = C . t}\end{array}$ \\
\hline 6686 & 0.01046 & 177.473 & 1.856371 \\
\hline 39125 & 0.005306 & 349.466 & 1.85427 \\
\hline 5965 & 0.002757 & 672.713 & 1.854671 \\
\hline 36379 & 0.001004 & 1848.395 & 1.855789 \\
\hline \multicolumn{3}{|c|}{ Average Viscosity } & 1.855275 \\
\hline Uncertainty & $\pm 0.07 \%$ \\
\hline
\end{tabular}

For group six, using oil No (05101) (Standard Reference Material 710A) as a transfer standard at $25{ }^{\circ} \mathrm{C}$ the viscometers in group 6 with known constant which are coming from its calibration certificates used to determine the viscosity of the oil No (05101), table 8.

Table (8): The viscosity of oil No. (05101) at $25{ }^{\circ} \mathrm{C}$.

\begin{tabular}{|c|c|c|c|}
\hline Oil No. & $\begin{array}{c}\text { Viscometer } \\
\text { No. }\end{array}$ & $\begin{array}{l}\text { Viscosity } \\
\left(\mathrm{mm}^{2} / \mathrm{s}\right)\end{array}$ & $\begin{array}{c}* \text { Uncertainty } \\
\left(\mathrm{mm}^{2} / \mathrm{s}\right)\end{array}$ \\
\hline $\begin{array}{c}05101 \\
\text { @ } \\
25^{\circ} \mathrm{C}\end{array}$ & $\begin{array}{c}1392 \\
790\end{array}$ & $\begin{array}{r}224961.55 \\
2496351\end{array}$ & \\
\hline & age & 224962.53 & \\
\hline \multicolumn{3}{|c|}{ Uncertainty } & $0.25 \%$ \\
\hline
\end{tabular}

\section{Conclusion}

An intensive work was carried out on studying the new metrological viscosity bath to realize the national viscosity scale in wide temperature ranges. The results show that the bath worked with stability better than $0.015{ }^{\circ} \mathrm{C}$. Thermal profile distribution achieved by two SPRTs calibrated at ITS-90 to calculate the thermal gradient homogenty. Thermal axial and radial gradient equivalent to $0.014{ }^{\circ} \mathrm{C}$ and $0.012{ }^{\circ} \mathrm{C}$ respectively. The selected groups of viscometers have been studied to determine the viscometer constant for unknown ones and known groups used to determine the viscosity of unknown oils by step-up-chain procedures.

\section{References}


A. Aliseda, E.J. Hopfinger, J.C. Lasheras, D.M. Kremer, A. Berchielli, E.K. Connolly: "Atomization of viscous and non Newtonian liquids by a coaxial, high-speed gas jet". Experiments and droplet size modeling, International Journal of Multiphase Flow 34 161$175(2008)$

ASTM D2162 (1992) Basic calibration of master viscometers and viscosity oil standards.

C. Pornpatkul, Temperature Sensor Calibration by Liquid Bath Control System, ICEAST 2012, International Conference on Engineering Applied Sciences and Technology, Nov 2124, 2012, Bangkok, Thailand.

Dullaert K, Mewis J "Non-Newtonian Fluids: An Introduction 3316. A structural kinetic model for thixotropy”. J Non-Newt Fluid Mech. 139: 21-30, (2006)

EURAMET/cg-13/v.2.0, Guide Line to Liquid Calibration Bath, 03/2011.

GUM, Guide to the expression of uncertainty in measurement BIPM/IEC/IFCC/ISO/OIML/IUPAC, (1995).

H. Preston-Thomas, International Temperature Scale1990 (ITS-90), National Research Council of Canada, Ottawa, KIA OSI, Canada (1990).

M. Ghazanfar .A Simple Method for the Calibration of an Open Surface Water Bath IOP Conf. Series: Materials Science and Engineering 51 (2013) 012015 doi:10.1088/1757899X/51/1/012015.

Standard Reference Material 710A, "Soda-Lime-Silica Glass"; National Institute of Standards \& Technology (NIST), Gaithersburg, MD, 20899, USA; March 20, (1991).

Standard Reference Material 717A, "Borosilicate Glass"; National Institute of Standards \& Technology (NIST), Gaithersburg, MD, 20899, USA; September 18, (1996).

$$
\begin{aligned}
& \text { الملخص باللغة العربية } \\
& \text { تحقيق المقياس القومي لللزوجه للمرة الثالثة عند درجات حرارة مختلفة } \\
& \text { ايمان محى الدين محمد 1، مصطفى محمود مكاوي 1'، هدى محمد أبوضره } 2 \\
& \text { المعهد القومى للقياس و المعايره } \\
& \text { كلية البنات للاداب و العلوم و التربية - جامعه عين شمس المس }
\end{aligned}
$$


اللزوجة هي الخاصية الفيزيقية التي تحدد القوة التي يجب التخلب عليها عندما تستخدم السوائل بين سطحي معدنيين أو هي التي تتحكم في انسياب السو ائل عند استخدامها في الطباعة و الدهانات و الطلاءو غير ذللك. تم تحقيق المقياس القومي للازوجة باستخدام المقاييس الزجاجية ذات الأنابيب الثعرية (الفسكوم ئز ات) و السو ائل العيارية ابتداء من الماء الذي تم تقطيرة مرتين و الذي تم الإتفاق عالميا علي أن تكون لزوجته عند درجة حرارة

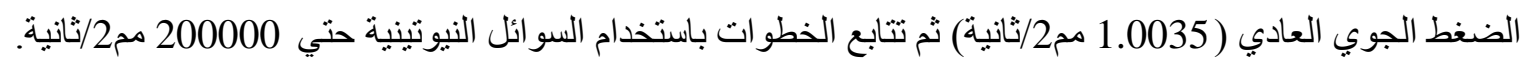
تمت در اسة للوسط الذي يوضع به الفسكو ميترات وهو حمام كحول وحمام زيت. الدر اسة شملت التوزيع الحر اري بداخله

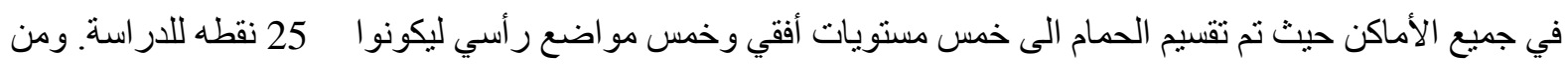
التوزيع الحراري وجد ان الوسط متجانس رأسي و افقي بفروق طفيفة تصل الى 0.012 و 0.014 سo على الترتيب ووجد أيضا ان مستوى الثبات للوسط يصل الى 0.015 س ${ }^{\circ}$ على مدار عده ساعات من التشغيل المتواصل. ومن النتائج تبين أن اللايقين في القراءات يتر اوح ما بي ن 0.7 \% بالنسبة للزيوت الخفيفة إلى $2.25 \%$ بالنسبة للزيوت الثقيلة. 